\title{
Portable XRF spectrometer with helium flow as a tool for lithological interpretation
}

\author{
Rafał Skupio \\ Oil and Gas Institute - National Research Institute, Well Logging Department; ul. Lubicz 25A, 31-503 Krakow, Poland; \\ e-mail: skupio@inig.pl; ORCID ID: 0000-0001-8273-4857 \\ (C) 2020 Author. This is an open access publication, which can be used, distributed and reproduced in any medium according \\ to the Creative Commons CC-BY 4.0 License requiring that the original work has been properly cited.
}

Received: 14 December 2020; accepted: 15 January 2021; first published online: 29 January 2021

\begin{abstract}
Portable EDXRF (Energy Dispersive X-Ray Fluorescence) spectrometer with the ability to perform rock tests in a helium atmosphere was applied to prepare unique calibration coefficients and mineralogical models. These data could be used for the chemical profiling, chemostratigraphy, gamma-ray, TOC and lithological interpretation of borehole geological profile. The measurements were conducted on 19 samples of sandstones and compared to the XRF data without helium flow. The acquired dataset was calibrated to the chemical laboratory tests (ICP-MS), gamma-ray spectrometry measurements (RT-50) and combined with the mineralogical data (XRD). The new methodology enables the measurement of sodium and enhances the possibility of detecting magnesium, thorium and uranium, compared to standard handheld XRF spectrometers. The applied method is dedicated to whole cores (without sample preparation) or cuttings which must be cleaned, dried, milled and pressed.
\end{abstract}

Keywords: portable XRF, elemental analysis, spectrometry, lithological interpretation, mineralogical models

\section{INTRODUCTION}

$\mathrm{X}$-ray fluorescence (XRF) techniques have been known since the 1950's and can be used as a partially destructive or non-destructive method for chemical composition analyses, depending on the type of material or desired data accuracy (Acquafredda 2019). Stationary geochemical methods such as inductively coupled plasma - mass spectrometry (ICP-MS), optical emission spectrometry (ICP-OES), instrumental neutron activation analysis (INAA), wavelength-dispersive X-ray fluorescence (WDXRF) or energy-dispersive XRF (EDXRF) are used for the quantitative chemical analysis of a broad range of elements (Kozak 2010, Rowe et al. 2012). All these laboratory techniques require sample preparation and calibration before tests. Handheld spectrometers, which use the energy-dispersive method (EDXRF), allow for rapid, non-destructive elemental analysis on clean drill cores or flat rock surfaces (Ogburn et al. 2012, Rowe et al. 2012). Rock fragments or core structures with surface unevenness can generate an important barrier in elemental analyses, and this is something that should be avoided (Liangquan et al. 1998). On the other hand, prepared samples such as pressed pellets or fused beds deliver high quality and repeatable results.

The Well Logging Department of the Oil and Gas Institute - National Research Institute has used the XRF method for geochemical rock analyses since 2013 (Skupio 2014) and a new methodology with helium flow for the last two years. XRF data enables the preparation of well profiles with elemental composition and mineralogy, as well as lithology interpretation. The interpretation is based on models which combine XRF results with chemical and mineralogical laboratory tests. XRF data are essential for verifying qualitative and quantitative results obtained by XRD 
analyses that can solve mineralogical uncertainties in analyzed rock samples (Loubser \& Verryn 2008). Besides, these non-destructive methods enable analyses to be conducted on cores where sampling is unviable. This makes it possible to prepare geochemical logs for archival boreholes, in which well logging services were not executed (Kowalska et al. 2018). XRF analyses are also conducted on the cuttings collected during the borehole drilling, which is using for the geosteering procedure (Chao et al. 2015). Furthermore, obtained elements profile could be used for the determination of gamma-ray (GR) based on K, U and Th (Skupio \& Dohnalik 2015), total organic carbon (TOC) content based on $\mathrm{Mo}, \mathrm{Ni}, \mathrm{Cu}$ (Alnahwi \& Loucks 2019) or brittleness index which depends on brittle mineral contents including quartz, calcite and dolomite (Yang et al. 2013, Yasin et al. 2017).

\section{METHODS AND MATERIALS}

A handheld Tracer 5g XRF spectrometer with the ability to perform tests in helium atmosphere was used for the research (Fig. 1A). It was equipped with a $1 \mu \mathrm{m}$ graphene window, $20 \mathrm{~mm}^{2}$ Silicon Drift Detector (SDD) with $<140 \mathrm{eV}, \mathrm{Mn}$ Ka resolution for optimum light element analysis. The excitation source is a rhodium (Rh) thin window $\mathrm{X}$-ray tube with maximum parameters as $50 \mathrm{kV}$, $200 \mu \mathrm{A}$ and $4 \mathrm{~W}$ (Bruker Corporation WWW). The analysis range is from $\mathrm{Na}$ to $\mathrm{U}$ (with $\mathrm{He}$

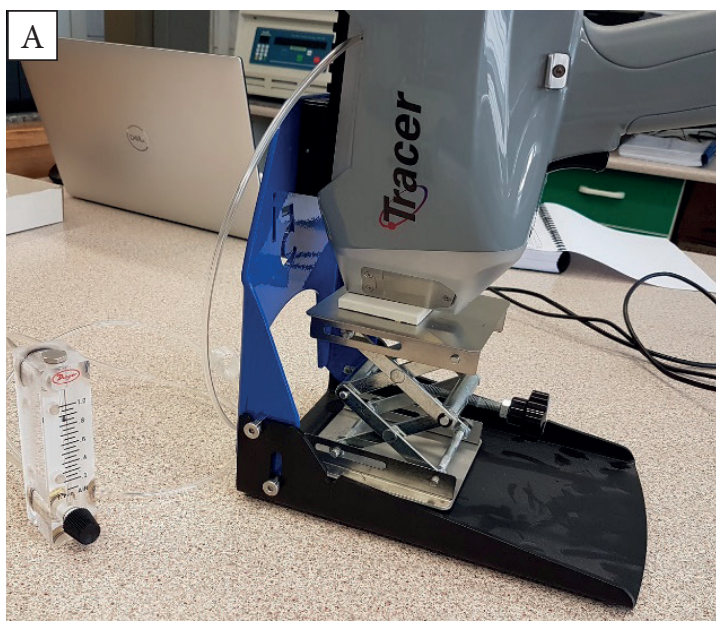

atmosphere), calibration for helium tests reaches 31 elements, whereas calibration without $\mathrm{He}$ detects 47 elements. Two separate measurements with both calibration methods allow the highest elemental analysis range to be achieved. In contrast, the standard Titan S1 spectrometer (without helium flow) was also applied. It is still used and has an analytical range from $\mathrm{Mg}$ to $\mathrm{U}$ (Skupio 2014). Both devices were developed by Bruker and after suitable calibration (Skupio \& Zagórska 2020), could be used alternately.

For high-quality measurements, 19 samples were collected from a sandstone drilling core. This material was cleaned, dried, milled, and pressed with a pressure force of 20 tons. The preparation procedure provides sample homogeneity and high repeatability of the measurements. Pellets (Fig. 1B) were tested with the helium flow of $0.6 \mathrm{~L} / \mathrm{min}$ and $240 \mathrm{~s}$ of measurement time in two phases. Light elements (first phase): $\mathrm{Na}, \mathrm{Mg}, \mathrm{Al}, \mathrm{Si}, \mathrm{P}, \mathrm{S}, \mathrm{Cl}, \mathrm{K}, \mathrm{Ca}$ and heavy elements (second phase) were separately detected. The same pellets were also tested with the use of a Titan spectrometer.

Parts of the milled samples were separated for chemical, mineralogical and natural gamma radioactivity analyses. Chemical analyses were conducted with the ICP-MS/OES method in an accredited geochemistry laboratory. Mineralogical measurements were done by the XRD method and the gamma-ray measurements were performed using an RT-50 stationary spectrometer with the 3 inch $\mathrm{NaI}(\mathrm{Tl})$ detector.

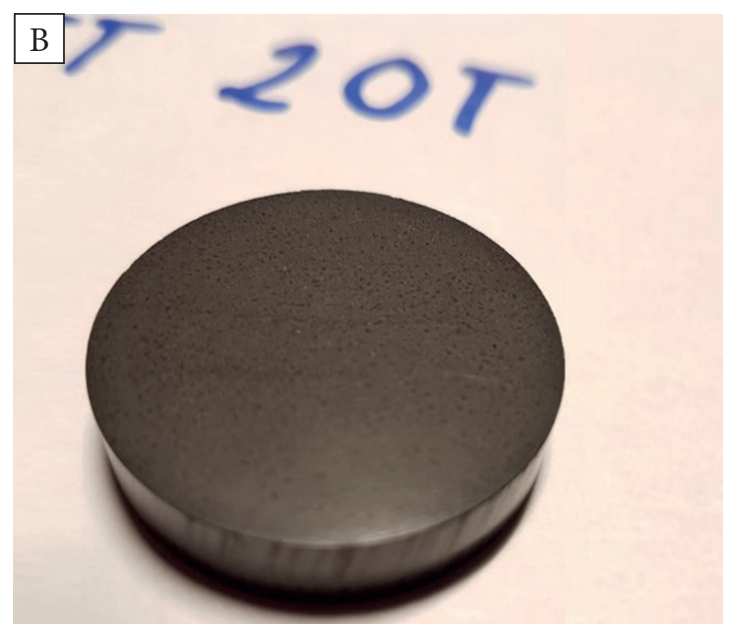

Fig. 1. Tracer $5 g$ spectrometer with a helium flow system (A). Pressed sample for XRF analysis (B) 


\section{RESULTS AND DISCUSSION}

Figure 2 shows an example of chemical data calibrations obtained from two spectrometers - Ti$\tan \mathrm{S} 1$ and Tracer $5 \mathrm{~g}$. For the calibration procedure presentation, $\mathrm{SiO}_{2}$ and $\mathrm{Al}_{2} \mathrm{O}_{3}$ results were correlated with the laboratory tests. These oxides are major components in the tested rock types and significantly different measured levels were obtained by the two spectrometers. During comprehensive lithological interpretation, the calibration procedure is also used for other elements occurring in the well profile (the range of elements depends on the rock type). FUS-ICP - technique employs a lithium metaborate/tetraborate fusion for sample preparation, analysis is by ICP-OES and ICP-MS.

The obtained data showed a strong correlation for the tested oxides by means of two different spectrometers and methods. $R^{2}$ for $\mathrm{SiO}_{2}$ and $\mathrm{Al}_{2} \mathrm{O}_{3}$ was about 0.89 and 0.91 for Titan and 0.92 and 0.93 for Tracer. High $R^{2}$ enables to calibrate results with high precision from both spectrometers in reference to stationary chemical tests. The data from measurements of suitably prepared samples are essential input for handheld XRF data calibrations and the development of mineral models.

The lightest elements as $\mathrm{Mg}$ and $\mathrm{Na}$ were also calibrated to thelaboratory tests(Fig.3). The helium method allowed the measurement of sodium and magnesium with high precision giving $R^{2}=0.81$ and 0.98. Standard XRF measurements were not efficient enough to detect $\mathrm{Na}$ and have no correlation for Mg. Additional analyses by Tracer in the air atmosphere showed $R^{2}=0.51$, which means that Tracer has better sensitivity for light elements even without helium application.
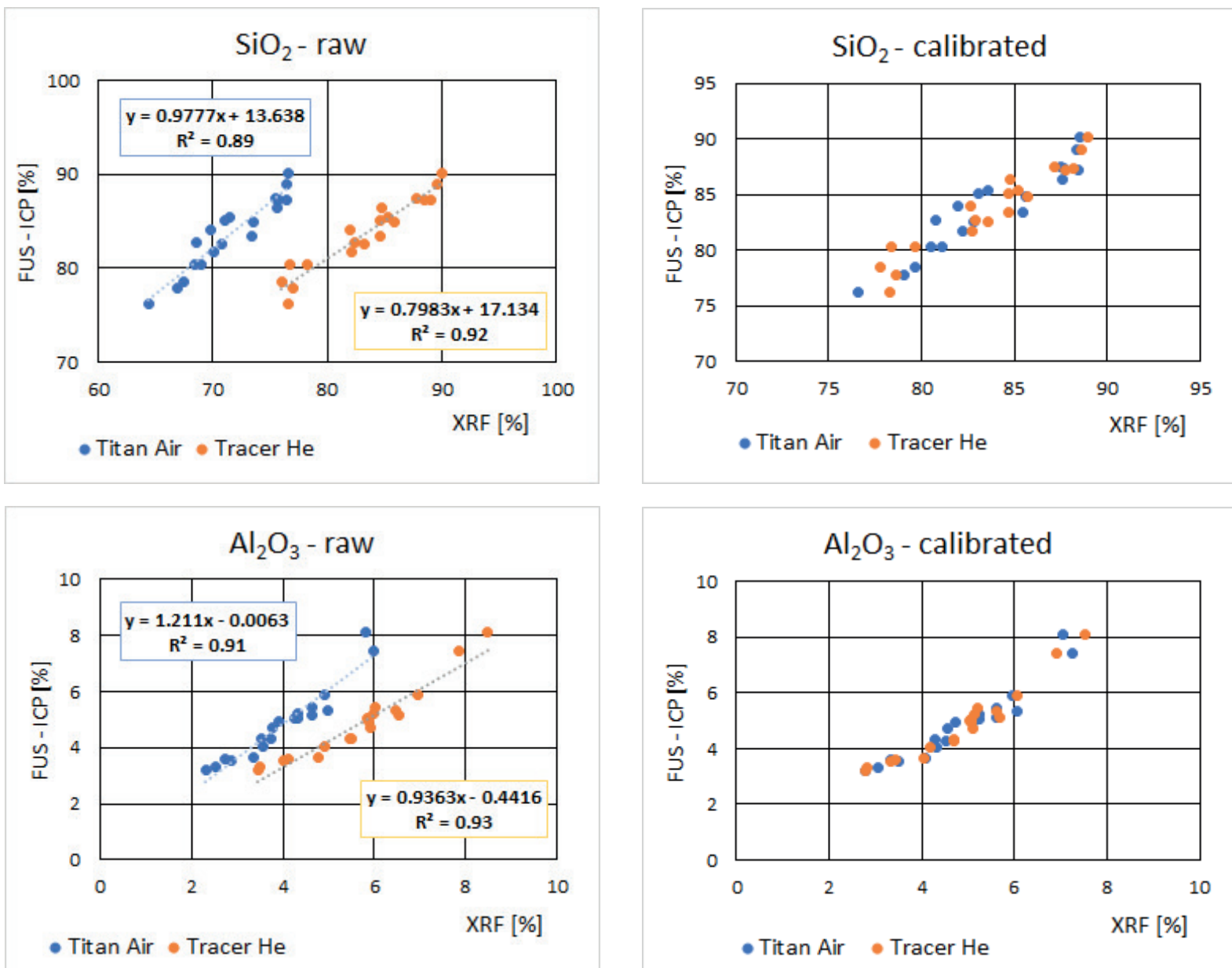

Fig. 2. Examples of correlation graphs for $\mathrm{SiO}_{2}$ and $\mathrm{Al}_{2} \mathrm{O}_{3}$ using Titan and Tracer spectrometers before and after the calibration procedure. Titan Air - the standard method, Tracer He - the measurement with helium flow 


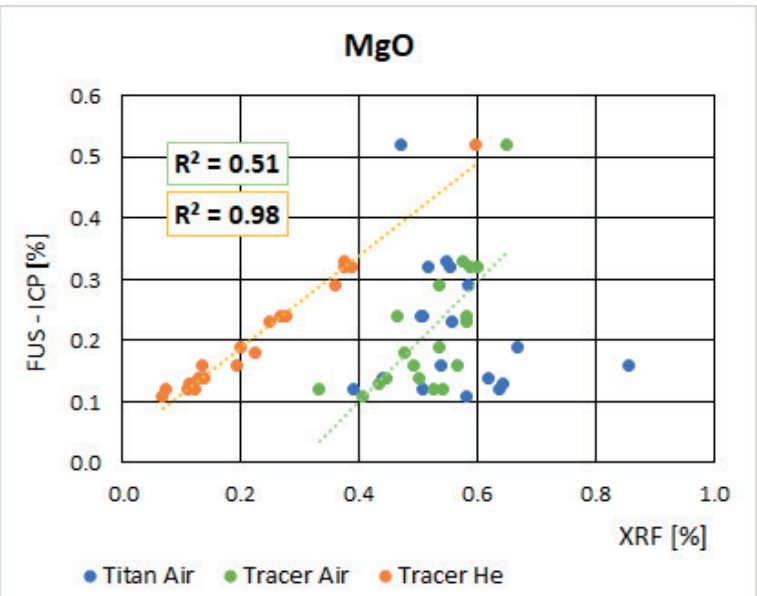

Fig. 3. $\mathrm{MgO}$ and $\mathrm{Na}_{2} \mathrm{O}$ correlation graphs for Titan and Tracer spectrometers with the laboratory data

Natural spectral gamma-ray data that could be used for shale volume calculation was also measured only with helium flow for uranium and thorium (potassium can be measured by means of a standard procedure). In Figure 4, XRF data were combined with laboratory tests (11 samples) and the $R^{2}$ was 0.98 for $\mathrm{K}$ and about 0.7 for uranium and thorium. Measurements for uranium and thorium were not complete because few samples had $\mathrm{U}$ and Th content below detection limits. For the tests on low radioactive rocks, a gamma spectrometer must be used.

Calibrated data are inserted into unique mineralogical models. In the comprehensive lithological interpretation, models are built for quartz $\left(\mathrm{SiO}_{2}\right)$,

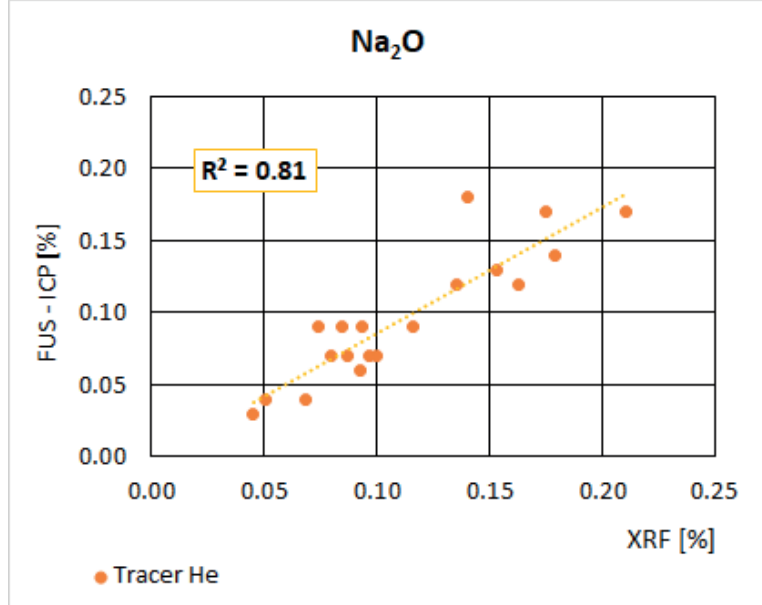

carbonates - calcite and dolomite $(\mathrm{MgO}, \mathrm{CaO})$, feldspars - sodium and potassium $\left(\mathrm{Na}_{2} \mathrm{O}, \mathrm{K}\right)$, anhydrite $(\mathrm{S})$, pyrite and hematite $\left(\mathrm{Fe}_{2} \mathrm{O}_{3}\right)$, barite $(\mathrm{Ba})$ and clay minerals as muscovite, illite, chlorite and kaolinite $\left(\mathrm{Al}_{2} \mathrm{O}_{3}, \mathrm{~K}, \mathrm{U}, \mathrm{Th}\right)$. Figure 5 shows examples of models for the most abundant minerals in tested samples as quartz, carbonates, the sum of clay minerals and feldspars, which were detected by Tracer with helium flow. Correlation coefficients are high for data from both spectrometers, which means Titan and Tracer could be used alternately. The helium method enables the measurements of sodium and magnesium, which allows for preparing additional models for sodium feldspars and dolomites.
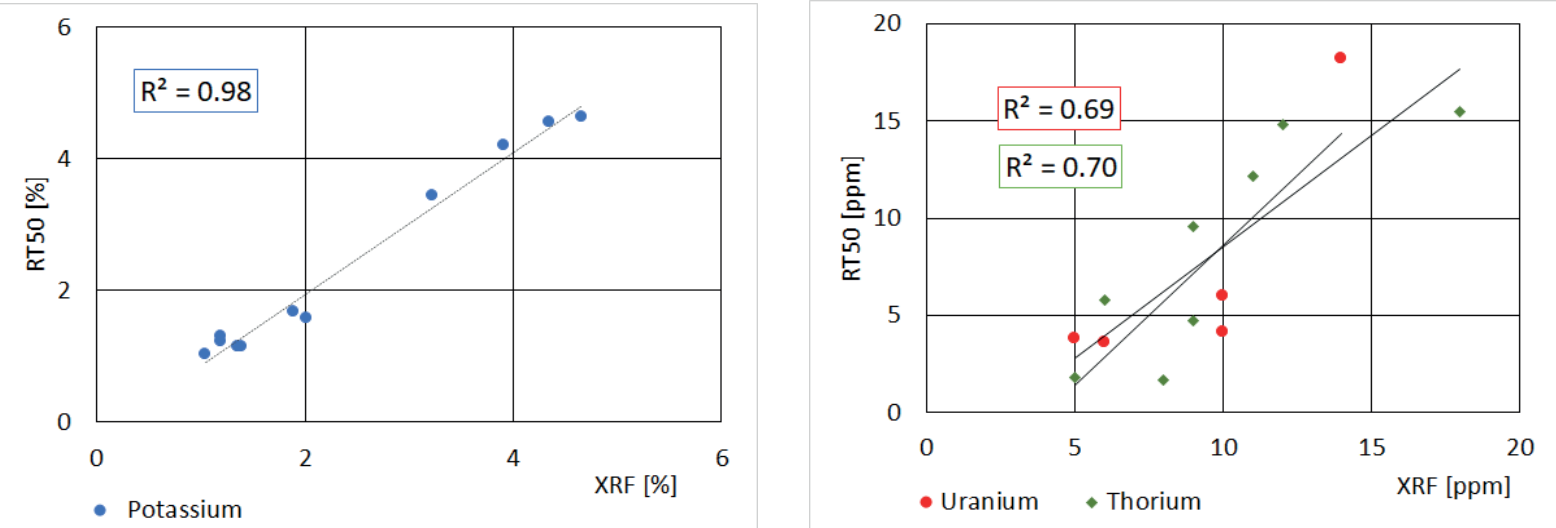

Fig. 4. Correlation of spectral gamma-ray data from laboratory tests and Tracer $5 g$ measured in helium atmosphere: $K$, U and Th 

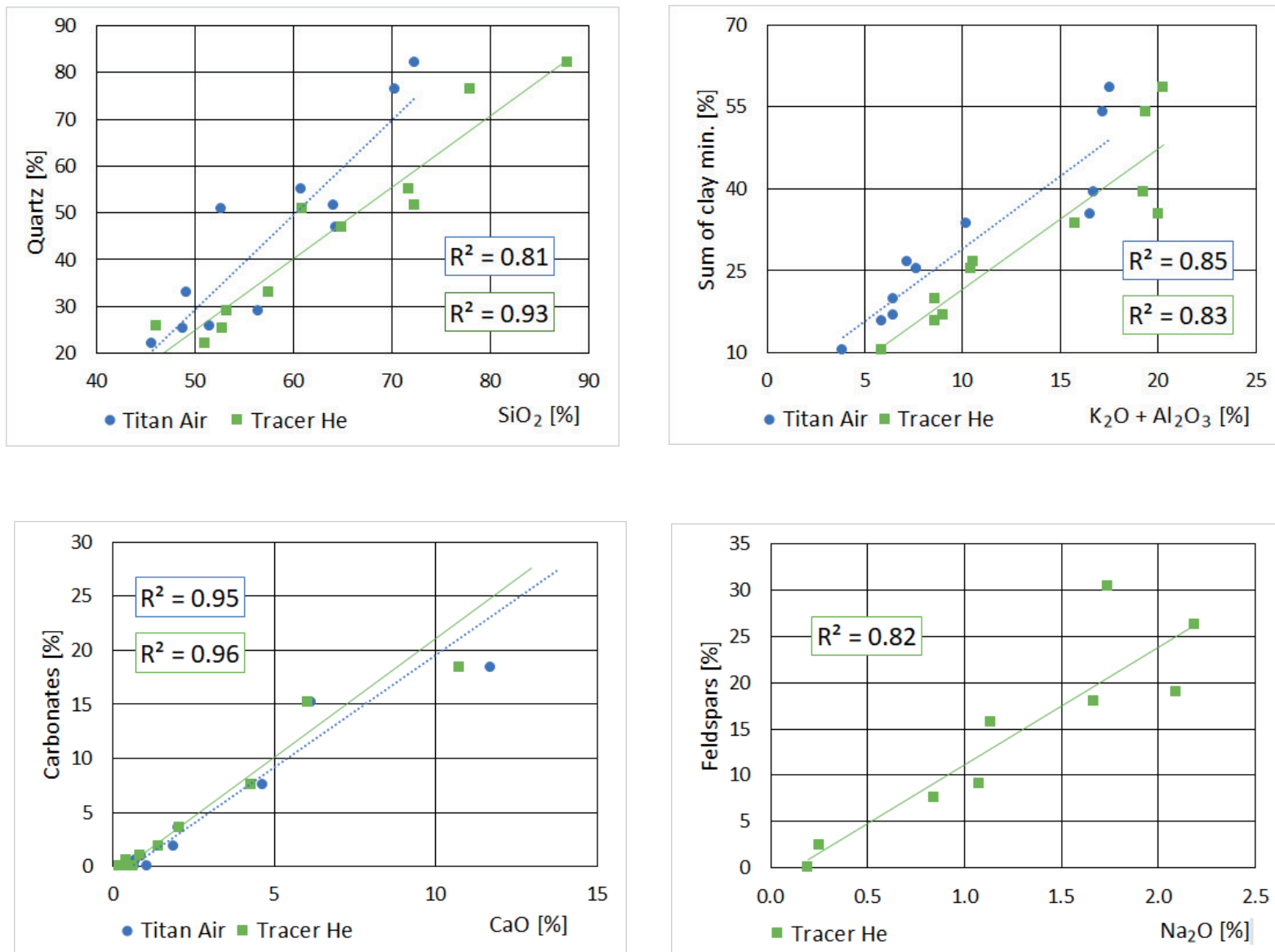

Fig. 5. XRF/XRD mineral models for lithology interpretation. Examples of models for quartz, the sum of clay minerals, carbonates and feldspars

\section{CONCLUSIONS}

XRF results from the helium method had higher correlation coefficients combined with laboratory data and much lower detection limits for light elements comparing to measurements conducted in the air atmosphere. The high-quality lithological interpretation based on XRF data is similar for most elements and minerals using the standard or helium method. Application of helium atmosphere and dedicated calibration for Tracer $5 \mathrm{~g}$ spectrometer improve the interpretation for dolomites and sodium feldspars, as well as shale volume with the use of $K, U$, and Th. The prepared models could be used for XRF data from measurements along boreholes (core or cuttings), in which samples were analyzed, or in boreholes from the same basin with a similar lithology and mineral composition.

\section{REFERENCES}

Acquafredda P., 2019. XRF Technique. Physical Sciences Reviews, 4, 8. https://doi.org/10.1515/psr-2018-0171.

Alnahwi A. \& Loucks R.G., 2019. Mineralogical composition and total organic carbon quantification using $\mathrm{x}$-ray fluorescence data from the Upper Cretaceous Eagle Ford Group in southern Texas. AAPG Bulletin, 103, 12, 2891-2907.

Bruker Corporation, www.bruker.com [access: 1.12.2020].

Chao Y., Cancan Z., Feng Z., Song H. \& Chaoliu L., 2015. A novel method for quantitative geosteering using azimuthal gamma-ray log. Applied Radiation and Isotopes, 96, 63-70.

Kowalska S., Kubik B., Skupio R. \& Wolański K., 2018. Rekonstrukcja profilu litologicznego na podstawie wyników pomiarów składu chemicznego rdzeni wiertniczych i próbek okruchowych. [in:] Rozwój technik poszukiwania i eksploatacji złóż węglowodorów: Geopetrol 2018: materiały konferencyjne, Instytut Nafty i Gazu, Kraków, $115-121$.

Kozak M., 2010. Zastosowanie optycznej spektrometrii emisyjnej, ze wzbudzeniem $\mathrm{w}$ plazmie indukowanej w badaniach przetworów naftowych. Nafta-Gaz, 7, 606-612. 
Liangquan G., Ye Z., Yeshun Ch. \& Wangchang L., 1998. The Surface Geometrical Structure Effect in in situ X-ray Fluorescence Analysis of Rocks. Applied Radiation and Isotopes, 49, 12, 1713-1720.

Loubser M. \& Verryn S., 2008. Combining XRF and XRD analyses and sample preparation to solve mineralogical problems. South African Journal of Geology, 111, 2-3, 229-238.

Ogburn D., Sillar B. \& Sierra J.C., 2012. Evaluating effects of chemical weathering and surface contamination on the in situ provenance analysis of building stones in the Cuzco region of Peru with portable XRF. Journal of Archaeological Science, 40, 4, 1823-1837.

Rowe H., Hughes N. \& Robinson K., 2012. The quantification and application of handheld energy-dispersive $\mathrm{x}$-ray fluorescence (ED-XRF) in mudrock chemostratigraphy and geochemistry. Chemical Geology, 324-325, $122-131$.
Skupio R., 2014. Wykorzystanie przenośnego spektrometru XRF do pomiarów składu chemicznego skał. Nafta-Gaz, $11,771-777$.

Skupio R. \& Dohnalik M., 2015. Improvement spectrometric gamma measurements on shale cores with the use of the BGO scintillation detector. Nafta-Gaz, 11, 847-855.

Skupio R. \& Zagórska U., 2020. Kalibracja wyników analiz chemicznych piaskowców czerwonego spągowca wykonanych przenośnym spektrometrem XRF. Nafta-Gaz, 1, 12-17.

Yang Y., Sone H., Hows A. \& Zoback M.D., 2013. Comparison of brittleness indices in organic-rich shale formations. [in:] 47th US Rock Mechanics / Geomechanics Symposium 2013. Vol. 2, American Rock Mechanics Association, 1398-1404.

Yasin Q., Du Q., Sohail G.M. \& Ismail A., 2017. Impact of organic contents and brittleness indices to differentiate the brittle-ductile transitional zone in shale gas reservoir. Geoscience Journal, 21, 779-789. 